\title{
Preliminary Report on the Cave Spider Fauna of the Ryukyu Archipelago
}

By

\section{Matsuei SHIMOJANA}

Futenma High School, Futenma, Ginowan City, Okinawa Prefecture, Japan

\section{Synopsis}

Shimojana, Matsuei (Futenma High School, Futenma, Ginowan City, Okinawa Prefecture): Preliminary report on the cave spider fauna of the Ryukyu Archipelago. Acta arachnol., 27 (Special number): 337-365 (1977).

A survey of the cave spider fauna in the Ryukyu Archipelago was carried out from 1966 to 1976 . Fourty two species of thirty six genera belonging to twenty three families were recorded from many limestone caves in the Ryukyu Islands. The representative cave spiders in the Ryukyu Archipelago are Masirana longipalpis, Falcileptoneta okinawaensis, Speocera laureata and Tetrablemma shimojanai etc. Among of them, Speocera laureata and Tetrablemma shimojanai are widely distributed in the Ryukyu Chain. The cave spider fauna of the Ryukyu Archipelago is much different from the Japanese Islands.

\section{Introduction}

The cave spider fauna of the Ryukyu Islands has been reported by Dr. T. Yaginuma $(1962,1970)$, Dr. T. Komatsu $(1968,1972,1974)$ and the present author (1973), but the number of recorded species is few and fragmentary.

Biospeleological survey of the Ryukyu Archipelago have been carried out by the author, and he has collected many kinds of subterranean animals from many limestone caves.

The present paper deals with the spider fauna disclosed during these surveys.

Before going further into the subjects, the author wishes to express his hearty thanks to Dr. Takeo Yagrnuma of Ohtemon Gakuin University, Osaka, Dr. Shun-ichi Ueno of National Science Museum, Tokyo, Dr. Sadao Ikehara of University of the Ryukyus, Okinawa, Dr. Toshihiro Komatsu of Matsumoto Dental College, Nagano and Dr. P. M. BRIGnoli of University of the Roma, Italy for their kind and helpful suggestions and advices during the course of this study. The author wishes to express his gratitude to Mr. Yoshio ArAKAK I of Futenma shrine, for his cooperation in Okinawa jima survey. 
Name of the limestone caves surveyed in the present paper

1. Nanatii-gama Cave; Takigawa, Kikai-cho, Kikai jima

2. Unnamed Cave: Takigawa, Kikai-cho, Kikai jima

3. Maeyama Cave: Tokuwase, Tokunoshima-cho, Tokuno shima

4. Nikeda Cave: Tokuwase, Tokunoshima-cho, Tokuno shima

5. Kenbuii Cave: Kami-kenbuku, Isen-cho, Tokuno shima

6. Kurago Cave: Kojima, Isen-cho, Tokuno shima

7. Shoryu-dō Cave: Tokutoki, China-cho, Okierabu jima

8. Taminanoho Cave: Tamina, China-cho, Okierabu jima

9. Erabu-dō Cave: China, China-cho, Okierabu jima

10. Hoonouko Cave: China, China-cho, Okierabu jima

11. Tenryu-dō Cave: Kamishiro, China-cho, Okierabu jima

12. Aasaki-abu Cave: Higashiku, Yoron-cho, Yoron jima

13. Yagoo Cave: Higashiku, Yoron-cho, Yoron jima

14. Toominali-abu Cave: Kajino, Yoron-cho, Yoron jima

15. Itsutenyagaa Cave: Nishizaki, Ie-son, Ie jima

16. Miitsu-abu Cave: Minatobaru, Ie-son, Ie jima

17. Nahanshri Cave: Kawahira, Ie-son, Ie jima

18. Niiyatiya Cave: Nishizaki, Ie-son, Ie jima

19. Unnamed Cave (A): Nishizaki, Ie-son, Ie jima

20. Unnamed Cave (B): Nishizaki, Ie-son, Ie jima

21. Taninukuchi-abu Cave: Hedo, Kunigami-son, Okinawa jima

22. Unnamed Cave: hedo, Kunigami-son, Okinawa jima

23. Tametomo-go Cave: Unten, Nakijin-son, Okinawa jima

24. Ushinusuru-gama Cave: Nakijin, Nakijin-son, Okinawa jima

25. Itsupiyaa-gama Cave: Oyadomari, Nakijin-son, Okinawa jima

26. Sumika-abu Cave: Sumikabaru, Motobu-cho, Okinawa jima

27. Tirano-gama Cave: Ishikawa, Motobu-cho, Okinawa jima

28. Nobaru-gama Cave: Nobaru, Motobu-cho, Okinawa jima

29. Nishi-buumabaru-dō Cave: Buumabaru, Buuma, Nago city, Okinawa jima

30. Awa-dō Cave: Buuma, Nago city, Okinawa jima

31. Miiga Cave: Matsuda, Ginoza-son, Okinawa jima

32. Angaa Cave: Matsuda, Ginoza-son, Okinawa jima

33. Shirohara-dō Cave: Shirohara, Ginoza-son, Okinawa jima

34. Nisshu-dō Cave: Kin, kin-son, Okinawa jima

35. Terano-gama Cave: Kadekaru, Ishikawa city, Okinawa jima

36. Kaabuya-gama Cave: Yamada, Onna-son, Okinawa jima 
37. Shimuku-gama Cave: Namihira, Yomitan-son, Okinawa jima

38. Tiira-gama Cave: Toya, Yomitan-son, Okinawa jima

39. Unnamed Cave: Toya, Yomitan-son, Okinawa jima

40. Amuji-gama Cave: Ikemi, Yonashiro-son, Miyagi jima

41. Ichimi-gama Cave: Ikemi, Yonashiro-son, Miyagi jima

42. Kanida-gama Cave: Uehara, Yonashiro-son, Miyagi jima

43. Mayaa-gama Cave: Uezu, Gushikawa city, Okinawa jima

44. Mayaa-gama Cave: Yohen, Yonashiro-son, Okinawa jima

45. Zukeran-dō Cave: Zukeran, Kitanakagushuku-son, Okinawa jima

46. Nakagusuku-dō Cave: Ooshiro, Kitanakagusuku-son, Okinawa jima

47. Izumi-dō Cave: Ooshiro, Kitanakagusuku-son, Okinawa jima

48. Futenmagu-dō Cave: Futenma, Ginowan city, Okinawa jima

49. Taabaru-gama Cave: Nodake, Ginowan city, Okinawa jima

50. Mayaa-abu Cave: Mashiki, Ginowan city, Okinawa jima

51. Agari-isagama Cave: Maehara, Ginowan city, Okinawa jima

52. Ryugu-dō Cave: Miyagi, Urasoe city, Okinawa jima

53. Yaaji-gama Cave: Kakinohana, Tamashiro-son, Okinawa jima

54. Kuraga Cave: Oyakebaru, Tamashiro-son, Okinawa jima

55. Tiira-gama Cave: Oyakebaru, Tamashiro-son, Okinawa jima

56. Ufuniku-gama Cave: Oyakebaru, Tamashiro-son, Okinawa jima

57. Gyokusen-dō Cave: Maekawa, Gushikami-son, Okinawa jima

58. Shinzato-dō Cave: Aragusuku, Gushikami-son, Okinawa jima

59. Yajaa-gama Cave: Kitahara, Gushikawa-son, Kume jima

60. Ganimanro-abu Cave: Kitahara, Gushikawa-son, Kume jima

61. Yatsuchino-gama Cave: Uezu, Gushikawa-son, Kume jima

62. Ohōbu-abu Cave: Uezu, Gushikawa-son, Kume jima

63. Narikawa-dō Cave: Nikadori, Hirara city, Miyako jima

64. Higashi-narikawa Cave: Nikadori, Hirara city, Miyako jima

65. Isagana Cave: Higa, Gusukube-cho, Miyako jima

66. Tsujupaga Cave: Higa, Gusukube-cho, Miyako jima

67. Abucha Cave: Nakahara, Gusukube-cho, Miyako jima

68. Chibisuki-abu Cave: Bora, Gusukube-cho, Miyako jima

69. Fukazoko Cave: Bora, Gusukube-cho, Miyako jima

70. Sabichigo Cave: Ibaruma, Ishigaki city, Ishigaki jima

71. Sakae-dō Cave: Sakae, Ishigaki city, Ishigaki jima

72. Inoda-iijaa Cave: Inoda, Ishigaki city, Ishigaki jima

73. Tajinano-abu Cave: Shiraho, Ishigaki city, Ishigaki jima 
74. Akamine-abu Cave: Shiraho, Ishigaki city, Ishigaki jima

75. Kaasunia-iijaa Cave: Oohama, Ishigaki city, Ishigaki jima

76. Nisufusuto-iijaa Cave: Oohama, Ishigaki city, Ishigaki jima

77. Daiichi Fukubuku-iijaa Cave: Shiinabaru, Ishigaki city, Ishigaki jima

78. Daini Fukubuku-iijaa Cave: Shiinabaru, Ishigaki city, Ishigaki jima

79. Maria-iijaa Cave: Nishitakebaru, Ishigaki city, Ishigaki jima

80. Daiichi Yanbaru-dō Cave: Yamabare, Ishigaki city, Ishigaki jima

81. Daichi Tabagabaru Cave: Kabira, Ishigaki city, Ishigaki jima

82. Daini Tabagabaru Cave: Kabira, Ishigaki city, Ishigaki jima

83. Taamoto-iijaa Cave: Kabira, Ishigaki city, Ishigaki jima

84. Yangaa-Cave: Kaijibaru, Taketomi-cho, Taketomi jima

85. Nanamarashi-abu Cave: Shihosabaru, Taketomi-cho, Taketomi jima

86. Zuruku-aboo Cave: Nakasuji, Taketomi-cho, Kohama jima

87. Kenno-abu Cave: Nakanobaru, Taketomi-cho, Kuro shima

88. Paimutii-abu Cave: Haebaru, Taketomi-cho, Kuro shima

89. Nakano-dō Cave: Nakano, Taketomi-cho, Iriomote jima

90. Ootomi-dō Cave: Ootomi, Taketomi-cho, Iriomote jima

91. Daini Ootomi-dō Cave: Ootomi, Taketomi-cho, Iriomote jima

92. Unnamed Cave: Ootomi, Taketomi-cho, Iriomote jima

93. Itokawarindo Cave: Toyohara, Taketomi-cho, Iriomote jima

94. Toyohara-dō Cave: Toyohara, Taketomi-cho, Iriomote jima

95. Hyandagu-abu Cave: Kubura, Yonaguni-cho, Yonaguni jima

96. Tarumai-abu Cave: Kubura, Yonaguni-cho, Yonaguni jima

97. Adigara Cave: Kubura, Yonaguni-cho, Yonaguni jima

98. Momotabaru-abu Cave: Momotabaru, Yonaguni-cho, Yonaguni jima

99. Ubunuti-abu Cave: Shiobaru, Yonaguni-cho, Yonaguni jima

100. Shiobaru-abu Cave: Shiobaru, Yonaguni-cho, Yonaguni jima

101. Runada-abu Cave: Sonai, Yonaguni-cho, Yonaguni jima

102. Unnamed Cave: Sonai, Yonaguni-cho, Yonaguni jima

103. Nichinhikidaya Cave: Sonai, Yonaguni-cho, Yonaguni jima

104. Konpira-dō Cave: Ikenosawa, Minami-Daito-son, Minami-Daito jima

105. Ashibikigo Cave: Toshima-mura, Takara jima

106. Kuiji-gama Cave: Kuijibaru, Tonaki-son, Tonaki jima

107. Takatabaru-gama Cave: Takatabaru, Tonaki-son, Tonaki jima

108. Habasakuno-gama Cave: Matsuobaru, Aguni-son Aguni jima

109. Kuyamabaru-gama Cave: Kuyamabaru, Nakijin-son, Kouri jima

110. Ushitura-gama Cave: Yonashiro-son, Ikei jima 


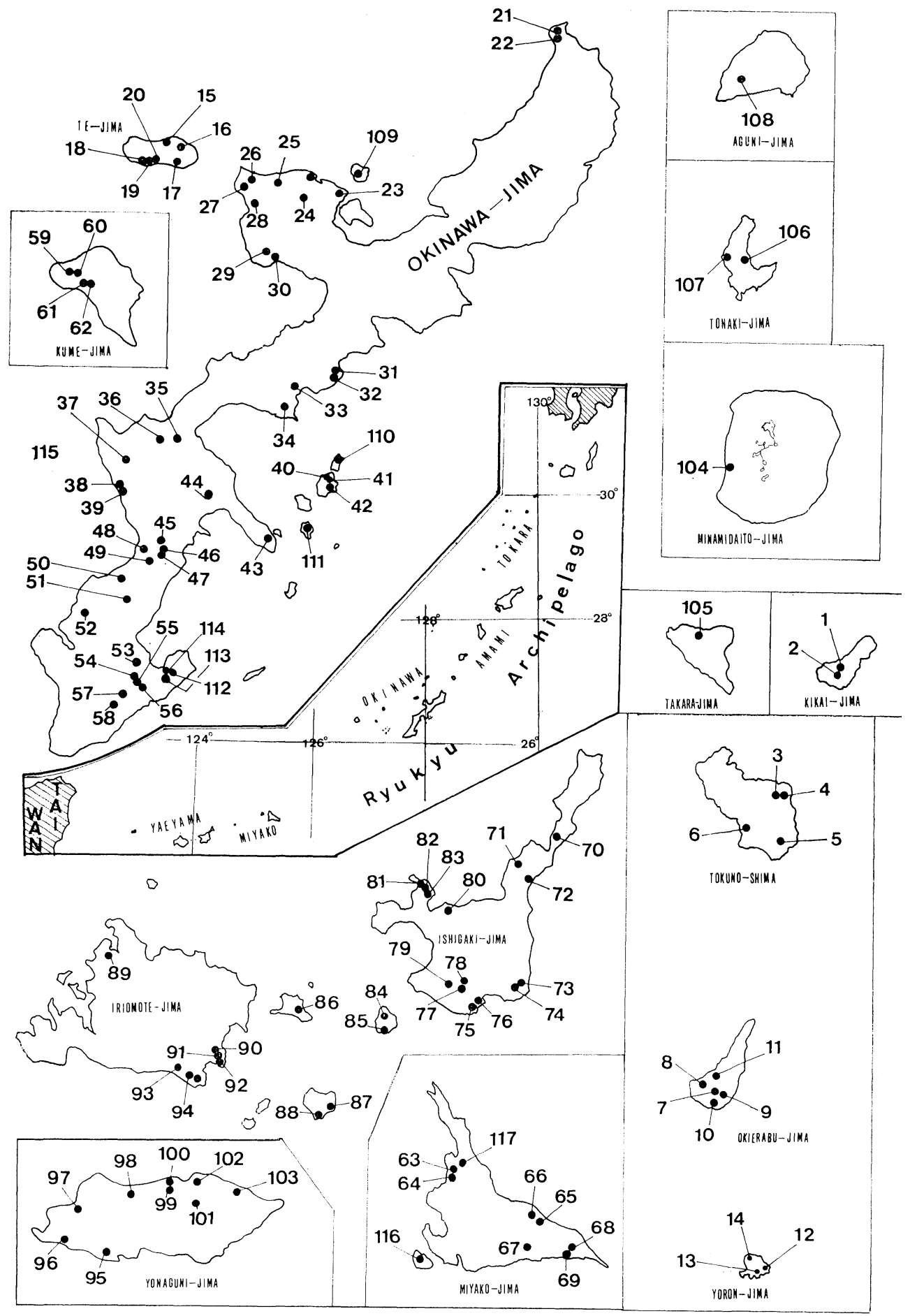

Fig. 1. The maps showing the location of limestone caves were investigated. 
111. Hamagaa Cave: Higa, Katsuren-son, Hamahiga jima

112. Angaa Cave: Chinen, Chinen-son, Okinawa jima

113. Jiibu-abu Cave: Shikiya, Chinen-son, Okinawa jima

114. Daiichi Funakubu-dō Cave: Funakubu, Sashiki-son, Okinawa jima

115. Abutu-gama Cave: Toya, Yomitan-son, Okinawa jima

116. Tsusaa-gaano-abu Cave: Izusumuyama, Shimoji-cho, Kurima jima

117. Genko-abu Cave: Nikadori, Hirara city, Miyako jima

\section{Results}

Spiders obtained from the limestone caves in the Ryukyu Archipelago are systematically arranged as follows:

\section{Family Heptathelidae}

\section{Heptathela kimurai (KISHIDA, 1923)}

Specimens examined: 1 female, Aug. 3, 1970, Agari-isagama Cave (No. 51); 2 females, Aug. 6, 1970, Terano-gama Cave(No. 35); 1 female, Aug. 22, 1970, Shimukugama Cave (No. 37); 1 female, Aug. 29, 1970, Mayaa-gama Cave (No. 44); 2 femal $\mho^{2}$, Feb. 8, 1971, Kaabuya-gama Cave (No. 36); 2 females, Aug. 30, 1971, Miiga Cave (No. 31); 2 females, Aug. 30, 1971, Shirohara Cave (No. 33); 1 female, Feb. 19, 1972, Taabarugama Cave (No. 49); 2 females, Aug. 1, 1972, Kurago Cave (No. 6); 2 female youngs, Aug. 2, 1972, Maeyama Cave (No. 3); 1 female, Sep. 9, 1972, Nobaru-gama Cave (No. 28); 1 female, Sep. 15, 1972, Kanida-gama Cave (No. 42); 1 female young, Sep. 24, 1972, Miitu-abu Cave (No. 16); 1 female, Oct. 8, 1972, Taninukuchi-abu Cave (No. 21); 1 female, Oct. 7, 1972, Tametomo-gama Cave (No. 23); 1 female, Oct. 7, 1972, Ushinusuru-gama Cave (No. 24); 1 female, Feb. 19, 1976, Angaa Cave (No. 32); 1 female, Feb. 19, 1976, Jiibu-abu Cave (No. 113); 1 female, Jun. 27, 1976, Daiichi Funakubu-dō Cave (No. 114).

This species is the most primitive spider known in Japan, which live in ground in a tube nest, the entrance of which has a trap door. The general appearance of this spider resembles that of the trap door spiders, but it is easily distinguished from them by the presence of marked tergal plates on the dorsum of the abdomen. This species is distributed from the southern area of Kyushu to Iriomote jima of the Ryukyus. The distribution of it seems to be related with the geological history of each island. Subterranean spider.

Distribution: Kyushu (southern area), Yaku shima, Tanega shima, Amami- 
ooshima, Tokuno shima, Okinawa jima, Ie jima, Miyagi jima, Tsuken jima, Hamahiga jima, Tokashiki jima, Kume jima, Ishigaki jima and Iriomote jima.

\section{Family Dipluridae}

Macrothele holsti Pocock, 1901

Specimens examined: 1 female, Oct. 26, 1972, Daiichi Fukubuku-iijaa Cave (No. 77); 1 female, Oct. 24, 1972, Ootomi-dō Cave (No. 90).

This spider builds a funnel-web in the ground, under stones or decayed trees in the forest. The burrow is composed of a silken tube, which leads into the nest. Nocturnal and subterranean species.

Distribution: Ishigaki jima, Iriomote jima, Formosa and China.

\section{Family Ctenizidae}

Latouchia swinhoei Pocock, 1901

Specimens examined: 1 female, Aug. 6, 1970, Terano-gama Cave (No. 35); 2 females, Feb. 1972, Taabaru-gama Cave (No. 49); 1 female, Sep. 2, 1972, Tiira-gama Cave (No. 55); 2 females, Jul. 17, 1972, Ufuniku-gama Cave (No. 56).

This species is a subterranean spider, which is distributed in the Ryukyu Chain. It is found from both inside and outside of the limestone cave.

Distribution: Okinawa jima, Kume jima, Miyagi jima, Tokuno shima, Kikai jima and Takara jima (Tokara Islands).

Ummidia fragaria (DoEnITZ, 1887)

Specimens examined: 1 female, May 3, 1965, Nakagusuku-dō Cave (No. 46); 2 females, Oct. 21, 1972, Ubunuti-abu Cave (No. 99); 1 female, Oct. 23, 1972, Adigara Cave (No. 97).

This trap door spider is widely distributed in Japan, which makes a tube-nest under the bark of trees. Nocturnal and scotophilous spider.

Distribution: Yonaguni jima, Kume jima, Okinawa jima, Amami ooshima, Kikai jima, Takara jima, Yaku shima, Tsu shima, Kyushu, Shikoku and Honshu.

\section{Family Uloboridae}

Uloborus geniculatus (OLIVIER, 1879)

Specimens examined: 1 female, Aug. 6, 1970, Terano-gama Cave (No. 35); 1 female, Sep. 8, 1970; 2 females, Feb. 19, 1972, Taabaru-gama Cave (No. 49); 1 female, 
Aug. 25, 1970, Nisshu-dō Cave (No. 34); 1 female, Aug. 26, 1971, Nishi-buumabaru-dō Cave (No. 29); 1 female, Sep. 24, 1972, Miitu-abu Cave (No. 16); 1 female young, Sep. 24, 1972, Itsutenyaga Cave (No. 15); 1 female, Oct. 26, 1972, Daiichi Fukubuku-iijaa Cave (No. 77).

This tropical spider is often found in the Ryukyu Islands. Scotophilous species.

Distribution: Yonaguni jima, Iriomote jima, Ishigaki jima, Miyako jima, Kume jima, Miyagi jima, Okinawa jima, Ie jima, Tonaki jima, Aguni jima, Kudaka jima, Amami ooshima, Takara jima and Nakano shima.

Uloborus varians BöSEnBERG et STRAND, 1906

Specimens examined: 3 females, Aug. 14, 1970, Yaaji-gama Cave (No. 53); 1 female, Aug. 6, 1970, Terano-gama Cave (No. 35); 1 female, Aug. 25, 1970, Nisshu-dō Cave (No. 34); 1 female, Aug. 29, 1970, Mayaa-gama Cave (No. 44); 3 females, 1 male, Sep. 8, 1970; 1 male, Feb. 19. 1970, Taabaru-gama Cave (No. 49); 1 male, Oct. 11, 1970, Futenmagu-dō Cave (No. 48); 1 female, Jul. 23, 1971, Abucha Cave (No. 67); 2 females, Jul. 23, 1971, Higashi-narikawa Cave (No. 64); 2 females, Jul. 23, 1971, Tsujupaga Cave (No. 66); 1 female, Jul. 23, 1971, Narikawa-dō Cave (No. 63); 1 female, Aug. 26, 1971, Awa-dō Cave (No. 30): 1 male, Aug. 1, 1972, Kurago Cave (No. 6); 1 female young, Jul, 31, 1972, Nanatii-gama Cave (No. 1); 2 females, Sep. 16, 1972, Amuji-gama Cave (No. 40); 1 male, Sep. 15, 1972, Kanida-gama Cave (No. 42); 1 female, Sep. 24, 1972, Nahanshari Cave (No. 17); 1 female, Oct. 8, 1972, Taninukuchi-abu Cave (No. 21); 2 females, Feb. 19, 1976, Angaa Cave (No. 32).

This species has the same habit as Uloborus geniculatus. It is a widely distributed spider in the Ryukyus and Japanes Islands. Scotophilous spider.

Distribution: Yaeyama Isls., Miyako Isls., Okinawa Isls., Amami Isls., Tokara Isls., Kyushu, Shikoku, Honshu, Hokkaido, Korea and Formosa.

\section{Family Oonopidae}

\section{Ischnothyreus narutomii (NAKATSUDI, 1942)}

Specimens examined: 1 female, Sep. 8, 1970, Taabaru-gama Cave (No. 49); 1 male, Feb. 22, 1971, Mayaa-gama Cave (No. 44); 1 male, Aug. 3, 1972, Shoryu-dō Cave (No. 7); 1 female, 1 female young, Sep. 8, 1972, Amuji-gama Cave (No. 40); 1 male, Sep. 16, 1972, Ichimi-gama Cave (No. 41).

This tiny spider lives under leaf litters in open woodland, but its habit are little known. Habitual trogloxenous spider.

Distribution: Okinawa jima, Miyagi jima, Okierabu jima, Yaku shima, Ogasawara, Izu Isls., Kyushu and Honshu. 


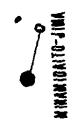

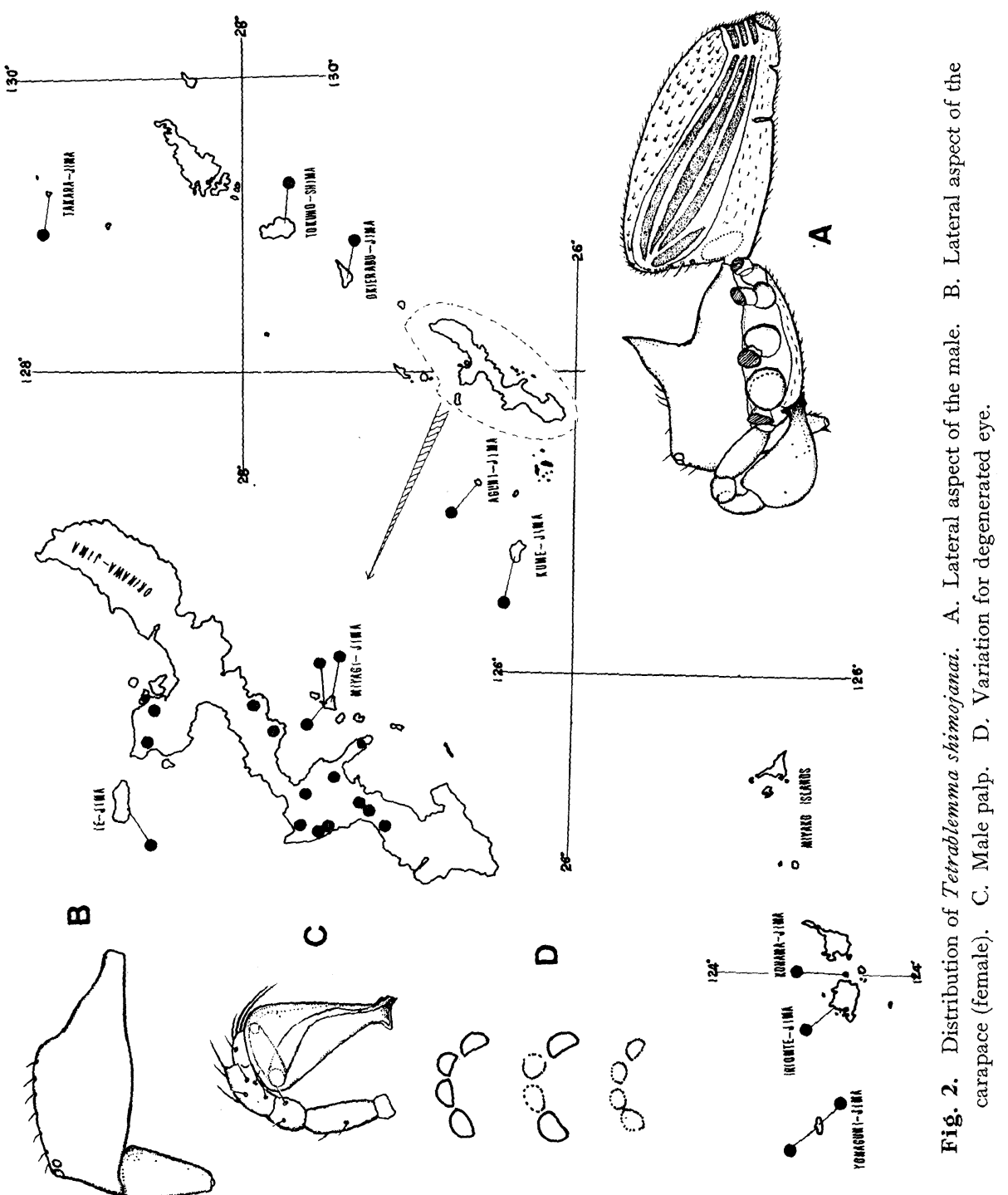




\section{Family Tetrablemmidae}

\section{Tetrablemma shimojanai Komatsu, 1968}

Specimens examined: 1 female and 2 males, Sep. 28, 1968: 3 females and 2 males, Aug. 6, 1970, Terano-gama Cave (No. 35); 2 females and 1 male, Jul. 24, 1970; 1 female, Jul. 28, 1972: 2 males, Dec. 19, 1975, Yajaa-gama Cave (No. 59); 1 female, Aug. 22, 1970, Shimuku-gama Cave (No. 37); 3 females and 1 male, Aug. 25, Nisshu-dō (No. 34); 2 females and 1 male, Aug. 29, 1970: 4 females, Jul. 25, 1972, Mayaa-gama Cave (No. 44); 3 females and 3 male, Sep. 8, 1970: 1 male, Feb. 19, 1972; 2 male, Jul. 1972, Taabaru-gama Cave (No. 49); 2 females, 22, 1971, Mayaa-abu Cave (No. 50); 2 females, Aug. 30, 1971, Angaa Cave (No. 32); 1 female, Feb. 22, 1972, Zukeran-dō Cave (No. 45); 2 females, Aug. 2, 1972, Maeyama cave (No. 3); 1 female, Aug. 3, 1972, Shoryu-dō Cave (No. 7); 4 females, 4 female youngs and 3 males, Sep. 2, 1972, Tira-gama Cave (No. 38); 1 female, Sep. 2, 1972, Abutu-gama Cave (No. 115); 2 males, Sep. 9, 1972, Nobaru-gama Cave (No. 28); 3 males, Sep. 16, 1972, Mayaa-gama Cave (No. 43); 3 females, 2 female youngs and 2 males, Sep. 15, 1972, Kanida-gama Cave (No. 42); 3 females and 1 male, Sep. 16, 1972, Amuji-gama Cave (No. 40); 4 females and 1 male, Sep. 16, 1972, Ichimi-gama Cave (No. 41); 1 male, Sep. 23, 1972, Niiyatia Cave (No. 18); 1 female and 1 male, Oct. 7, 1972, Tametomo-gama Cave (No. 23); 1 female and 1 male, Oct. 7, 1972, Ushinusuru-gama Cave (No. 24); 1 male, Oct. 21, 1972, Ubunutiabu Cave (No. 99); 1 female and 1 male, Oct. 23, 1972, Runada-abu Cave (No. 101); 1 male, Oct. 29, 1972, Zuruku-aboo Cave (No. 86); 1 male, Aug. 23, 1973, Nakano-do Cave (No. 89); 2 males, May. 29, 1974, Habaa-sakuno-gama Cave (No. 108); 2 females and 1 male, Jun. 9, 1974, Konpira-dō Cave (No. 104).

This tiny spider is often found in the limestone caves, which is a widely distributed species in the Ryukyu Chain. It is an endemic species in the Ryukyu Islands. Habit of this spider are little known. It is remarkable that Tetrablemma shimojanai has been found to coexist with Hexablemma sp. only in Nakano-dō Cave on Iriomote jima. Troglophilous spider.

Distribution: Yonaguni jima, Iriomote jima, Kohama jima, Ishigaki jima, Okinawa jima, Miyagi jima, Ie jima, Aguni jima, Kume jima, Minami-Daito jima, Okierabu jima, Tokuno shima and Takara jima (Tokara Islands).

\section{Family Leptonetidae}

Falcileptoneta okinawaensis KomAtsu, 1972

Specimens examined: 3 females, Aug. 22, 1970, Shimuku-gama Cave (No. 37); 12 females and 2 males, Aug. 25, 1970, Nisshu-dō Cave (No. 34); 3 females and 1 male 
and 1 male young, Sep. 16, 1972, Mayaa-gama Cave (No. 44); 2 males, Feb. 22, 1971: 3 females and 1 male, Jul. 25, 1972, Mayaa-abu Cave (No. 50); 2 femals, Oct. 7, 1972, Tametomo-gama Cave (No. 23); 2 females and 1 male, Oct. 14, 1972, Futenmagu cave (No. 48).

This spider spins a sheet-web in dark places at the entrance of the limestone caves. Probably a troglophilous spider.

Distribution: Okinawa jima.

\section{Masirana longipalpis Komatsu, 1972}

Specimens examined: 5 females, Aug. 6, 1970; 1 female and 1 male, Jul. 23, 1972, Terano-gama Cave (No. 35); 5 males, Aug. 25, 1970, Nisshu-dō Cave (No. 34); 3 females and 2 males, Aug. 29, 1970, Mayaa-gama Cave (No. 44); 2 females and 3 males, Feb. 22, 1971; 1 female and 1 male, Jul. 7, 1972: 5 females and 1 male, Jul. 25, 1972, Mayaa-abu Cave (No. 50); 1 male, Feb. 8, 1971, Kaabuya-gama Cave (No. 36); 6 females, 4 female youngs and 5 males, Aug. 26, 1971, Nishi-buumabaru-dō Cave (No. 29); 3 females and 2 males, Aug. 30, 1971, Shirohara-dō Cave (No. 33); 2 females, Aug. 30, 1971, Angaa Cave (No. 32); 2 females, 4 female youngs and 2 males, Sep. 9, 1972, Nobaru-gama Cave (No. 28); 1 female, 4 males and 1 male young, Sep. 15, 1972, Kanida-gama Cave (No. 42); 16 females, 4 female youngs, 6 males and 2 male youngs, Sep. 16, 1972, Amuji-gama Cave (No. 40); 10 females, 2 female youngs, 2 males and 1 male young, Sep. 16, 1972, Ichimi-gama Cave (No. 41); 1 female, 2 female youngs, 1 male and 1 male young, Sep. 24, 1972, Itsutenyaga Cave (No. 15); 5 females, 1 female young and 5 males, Sep. 24, 1972, Miitu-abu Cave (No. 16); 5 females, 3 female youngs, 4 males and 1 male young, Oct. 7, 1972, Ushinusuru-gama Cave (No. 24); 2 females and 2 males, Feb. 19, 1976, Jiibu-abu Cave (No. 113); 3 females and 1 male, Feb. 19, 1976. Angaa Cave (No. 112); 4 females and 2 males, Jul. 24, 1970: 3 females and 2 males, Jun. 24, 1974: 2 females and 1 male, Jul. 27, 1972, Yajaa-gama Cave (No. 59); 2 females and 3 males, Jul. 28, 1972, Ganimanro-dō Cave (No. 60); 2 females and 1 male, Jul. 28, 1972, Ohō bu-abu Cave (No. 62); 3 females and 3 males, May 9, 1974, Kuijibaru-gama Cave (No. 106); 1 female, 2 female youngs, 1 male and 1 male young, May 9, 1974, Takatabaru-gama Cave (No. 107); 5 females, 2 female youngs, 6 males and 1 male young, Oct. 26, 1972, Maria-iijaa Cave (No. 79); 5 females, 2 female youngs and 3 males, Oct. 26, 1972, Daiichi Fukubuku-iijaa Cave (No. 77); 9 females, 1 female young and 2 males, Oct. 28, 1972: 2 females and 1 male, Mar. 29, 1973, Inoda-iijaa Cave (No. 72); 1 female and 2 males, Oct. 28, 1972, Sabichigo Cave (No. 70); 7 females, 2 female youngs and 2 males, Oct. 28, 1972, Sakae-abu cave (No. 71).

One of the representative spider of the troglobiontic species in the Ryukyu Islands, 


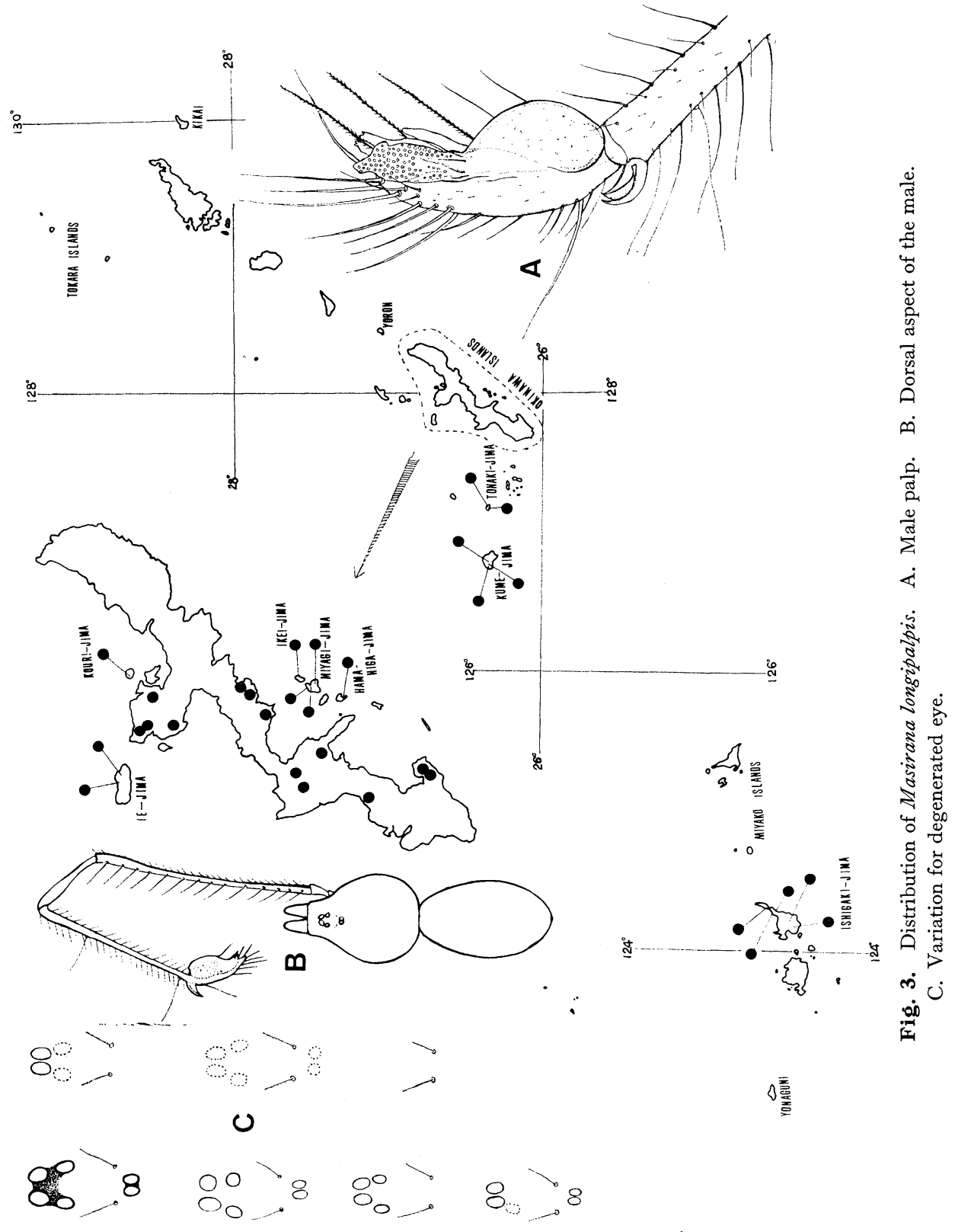

AORMOSA 


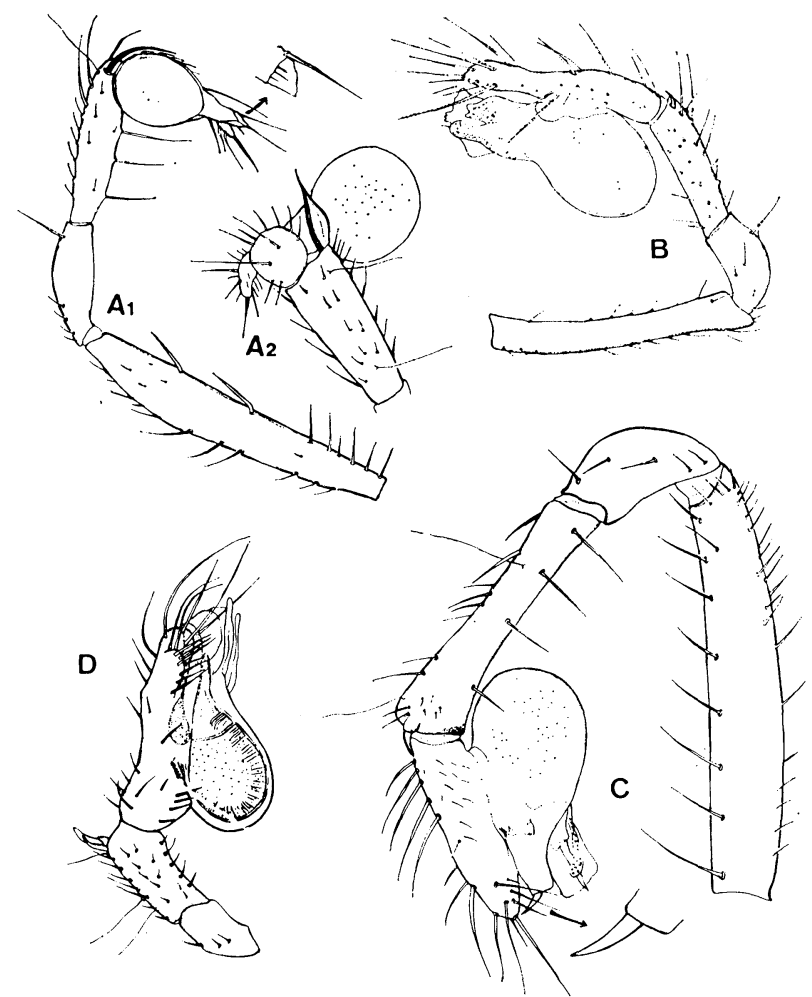

Fig. 4. A-1,2: Leptoneta sp., of Toominari Cave on Yoron jima; male palp.

B. Leptoneta sp., of Nanatii-gama Cave on Kikai jima; male palp.

C. Leptoneta sp., of Kenbuii Cave on Tokuno shima; male palp.

D. Falcileptoneta okinawaensis of Shimuku-gama Cave on Okinawa jima.

which is adapted in a subterranean environments. This species is not found in Miyako Islands, Daito Islands and Aguni jima (Okinawa Islands).

In Yaeyama Islands, this species is found only on Ishigaki jima. It seems that the distribution of this species has relation to the geological history and topography (espicially altitude of the limestone plateau) of each island.

\section{Family Telemidae}

\section{Speocera laureata KomAtsu, 1974}

Specimens examined: 6 females and 4 males, Aug. 26, 1971: 1 female and 2 males, Jul. 25, 1972, Mayaa-gama Cave (No. 44); 1 male, Sep. 8, 1970: 2 females and 1 male, Jul. 25, 1972: 2 females, Feb. 19, 1972, Taabaru-gama Cave (No. 49); 2 females and 1 male, Sep. 28, 1965: 4 females and 2 males, Aug. 6, 1970: 2 females and 1 male, Jul. 


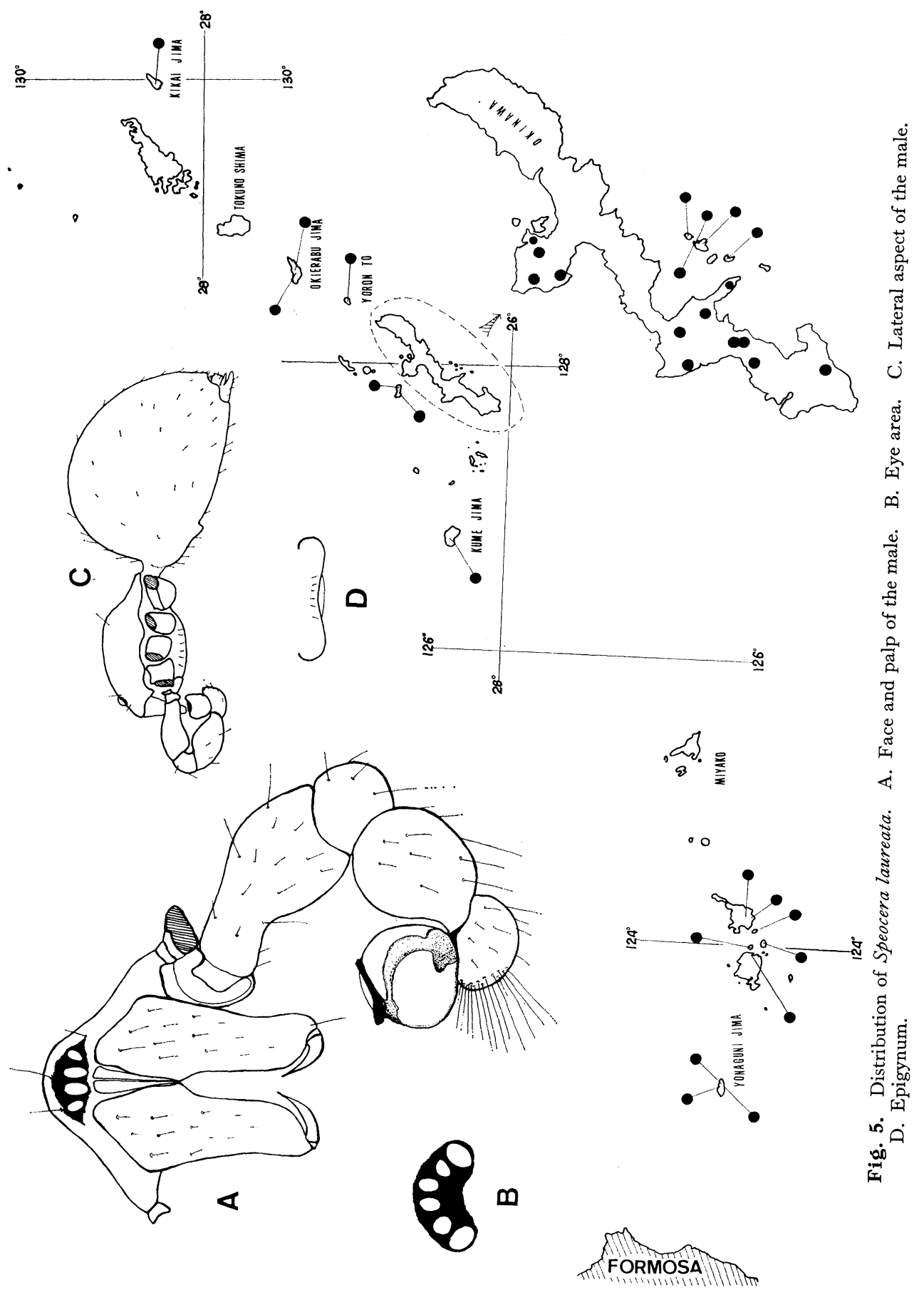


23, 1972, Terano-gama Cave (No. 35); 1 male, Aug. 26, 1971, Nishi-buumabaru Cave (No. 29); 4 females, Sep. 9, 1972, Nobaru-gama Cave (No. 28); 2 male and 1 male young, Sep. 16, 1972, Mayaa-gama Cave (No. 43); 1 female, Feb. 22, 1972, Zukeran-dō Cave (No. 45); 2 females, 2 female youngs and 2 males, Jul. 17, 1972, Shinzato-dō Cave (No. 58); 7 females and 1 male, Sep. 2, 1972, Tira-gama Cave (No. 38); 2 females and 2 males, Oct. 7, 1972, Ushinusuru-gama Cave (No. 24); 5 females and 2 males, Oct. 7, 1972, Tametomo-gama Cave (No. 23); 1 female and 1 male, Sep. 15, 1972, Kanida-gama Cave (No. 42); 5 females, 1 female young and 2 males, Sep. 16, 1972, Amuji-gama Cave (No. 40); 2 males and 1 male young, Sep. 16, 1972, Ichimi-gama Cave (No. 41); 8 females and 1 male, Sep. 24, 1972, Miitu-abu Cave (No. 16); 2 females, Sep. 24, 1972, Niiyatia Cave (No. 18); 3 females and 2 males, Aug. 6, 1972, Toominari-abu Cave (No. 14); 1 female, 1 female young and 1 male, Aug. 5, 1972, Tenryu-dō Cave (No. 11); 1 female, Aug. 3, 1972, Shoryu-do Cave (No. 7); 2 female and 2 males, Jul. 31, 1972, Nanatii-gama Cave (No. 1); 1 male, May 16, 1974, Ushitura-gama Cave (No. 110); 1 female and 3 males, May 15, 1974, Hamagaa Cave (No. 111); 1 female and 1 male young, May 10, 1974 Tera-gama Cave (No. 35); 1 female, Oct. 22, 1972, Tarumai-abu Cave (No. 96); 1 female and 2 males, Oct. 21, 1972, Ubunuti-abu Cave (No. 99); 2 females, Oct. 21, 1972, Shiobaru-gama Cave (No. 100); 1 male, Oct. 22, 1972, Hyandagu-abu Cave (No. 95); 1 female and 1 male, Oct. 27, 1972, Kenno-abu Cave (No. 87); 3 females and 2 males, Aug. 6, 1973, Ootomi-dō Cave (No. 90); 1 female, Oct. 29, 1972, Zurukuaboo Cave (No. 86); 3 females and 2 males, Oct. 25, 1972, Nanamarashi-abu Cave (No. 85); 2 females, Oct. 26, 1972, Kaasunia-iijaa Cave (No. 75); 2 females and 2 males, Oct. 28, 1972, Sakae-do Cave (No. 71) 2 females and 1 male, Aug. 8, 1973, Daini Fukubukuiijaa Cave (No. 78).

This is a very small spider, and is found in Okinawa, Yaeyama and Amami Islands. Habit of this species is similar to that of Tetrablemma shimojanai.

\section{Family Scytodidae}

\section{Scytodes thoracica (LATREILLE, 1804)}

Specimens examined: 1 female, Aug. 6, 1970, Terano-gama Cave (No. 35); 1 female, Sep. 2, 1972, Tirano-gama Cave (No. 29); 1 female, Sep. 23, 1972, Niiyatia Cave (No. 18).

This spider is frequently found in dark places in the forest or in the houses. This species is widely distributed in the world. Scotophilous spider.

Distribution: Yaeyama Isls., Miyako Isls., Okinawa Isls., Amami Isls., Tokara Isls., Tsushima, Kyushu, Honshu, Shikoku, Hokkaido, Formosa, Korea and China. 


\section{Family Pholcidae}

Smeringopus pallidus (BLACKWALL, 1858)

Specimens examined: 1 female, Aug. 6, 1970, Terano-gama Cave (No. 35); 2 females, Aug. 25, 1970, Nisshu-do Cave (No. 34); 2 females, Nov. 8, 1971, Kaabuyagama Cave (No. 36); 1 female, Aug. 26, 1971, Awa-dō Cave (No. 30); 1 female, Aug. 30, 1971, Angaa Cave (No. 32) ; 2 females, Aug. 30, 1971, Miiga Cave (No. 31) ; 3 females, Jul. 23, 1971, Abucha Cave (No. 67); 1 female, Jul. 23, 1971, Chibisuki-abu Cave (No. 68); 1 female, Jul. 23, 1971, Fukajoko Cave (No. 69); 1 female, Jul. 23, 1971, Isagana Cave (No. 65); 2 females, Jul. 24, 1971, Nisufusuto-iijaa Cave (No. 76); 1 female, Feb. 22, 1972, Zukeran-dō Cave (No. 45); 1 female, Sep. 16, 1972, Amuji-gama Cave (No. 40); 2 females, Sep. 16, 1972, Ichimi-gama Cave (No. 41); 2 females, Oct, 7, 1972, Ushinusuru-gama Cave (No. 24); 1 female, Oct. 26, 1972, Maria-iijaa Cave (No. 79); 1 male, Oct. 28, 1972, Sabichigo Cave (No. 70); 1 female, Oct. 27, 1972, Akamine-abu Cave (No. 74); 1 female, Oct. 27, 1972, Tajinano-abu Cave (No. 73); 1 female, Oct. 26, 1972, Kaasunia-iijaa Cave (No. 75); 2 females, Oct. 29, 1972, Zuruku-aboo Cave (No. 86); 1 female, Oct. 27, 1972, Paimutii-abu Cave (No. 78); 1 female, Oct. 24, 1972, Ootomi-do Cave (No. 90); 2 females, Oct. 24, 1972, Daini Ootomi-dō Cave (No. 91); 1 female and 1 male, Oct. 22, 1972, Tarumai-abu Cave (No. 96); 2 female youngs, Oct. 21, 1972, Ubunuti-abu Cave (No. 99); 1 female, Oct. 22, 1972, Nichinhikidaya Cave (No. 103); 1 female young, Oct. 23, 1972, Adigara Cave (No. 97); 2 females, Feb. 19, 1976, Jiibuabu Cave (No. 112).

This is a widely distributed species in the Ryukyu Islands, which is often found in dark places in human dwellings or in the forest. Scotophilous spider.

Distribution: Ryukyu Islands, Ogasawara and Formosa.

\section{Family Theridiidae}

\section{Coleosoma blandum O. P. CAMBRIDGE, 1882}

Specimen examined: 1 female, Feb. 22, 1972, Zukeran-dō Cave (No. 45).

This spider has a unique shape of abdomen, and it lives in fallen litters or debris in the forest. Habit of this spider is little known. Trogloxenous spider.

Distribution: Okinawa jima, Yoron jima, Okierabu jima, Yaku shima, Honshu and Ceylon.

\section{Conopistha fissifrons (O. P. CAMBRIDGE, 1869)}

Specimens examined: 2 females and 1 male, Aug. 30, 1971, Miiga Cave (No. 31). This spider is a widely distributed species in the Ryukyu Islands. It inhabits in 
the web of other spiders. Accidental trogloxenous spider.

Distribution: Ryukyu Islands, Tokara Islands, Tsushima, Kyushu, Shikoku, Honshu, Formosa and China.

\section{Conopistha bonadea KARSCH, 1881}

Specimen examined: 1 female, Aug. 30, 1971, Miiga Cave (No. 31).

The habit of this species is similar to that of Conopistha fissifrons. A specimen was collected from the web of Cyrtophora moluccensis. Accidental trogloxenous spider.

Distribution: Ryukyu Islands, Tokara Islands, Tsushima, Kyushu, Shikoku and Honshu.

\section{Theridion tepidariorum (C. $\mathrm{KocH}, 1841)$}

Specimens examined: 3 females, Aug. 14, 1970, Yaaị-gama Cave (No. 53); 3 females, Aug. 26, 1970, Nisshu-dō Cave (No. 34); 1 female and 1 male, Aug. 30, 1971, Shirohara-dō Cave (No. 33); 4 females and 1 male, Oct. 11, 1970, Futenmagu-dō Cave (No. 48); 1 female, Aug. 30, 1971, Angaa Cave (No. 32); 1 female and 1 female young, Aug. 6, 1972, Terano-gama Cave (No. 35); 1 female, Sep. 2, 1972, Abutu-gama Cave (No. 115); 1 female, Sep. 2, 1972, Tira-gama Cave (No. 38).

This cosmopolitan spider is often found in dark places or shady fields near human dwellings or open woodland. Scotophilous spider.

Distribution: Ryukyu Islands, Tokara Islands, Tsushima, Kyushu, Shikoku, Honshu, Hokkaido, Formosa, Korea and China.

\section{Family Nesticidae}

\section{Nesticus mogera Yaginuma, 1972}

Specimens examined: 1 male, Aug. 11, 1974, Tsusaa-gaano-abu Cave (No. 116); 1 male, Aug. 12, 1974, Genko-abu Cave (No. 117).

This is a short-legged nesticid spider found only from the limestone cave in the Ryukyu Chain. But in the Japanese Islands, this species is recorded from both inside and outside of the cave.

In Miyako Islands, this species builds an irregular web in rock-hall or under decayed $\log \mathrm{s}$ in the limestone caves.

The eyes and body-color of the individuals of Miyako Islands are completely degenerated. The author has collected many other individuals belonging to genus Nesticus from the limestone caves on Yonaguni jima, Okinawa jima, Ie jima, Kume 

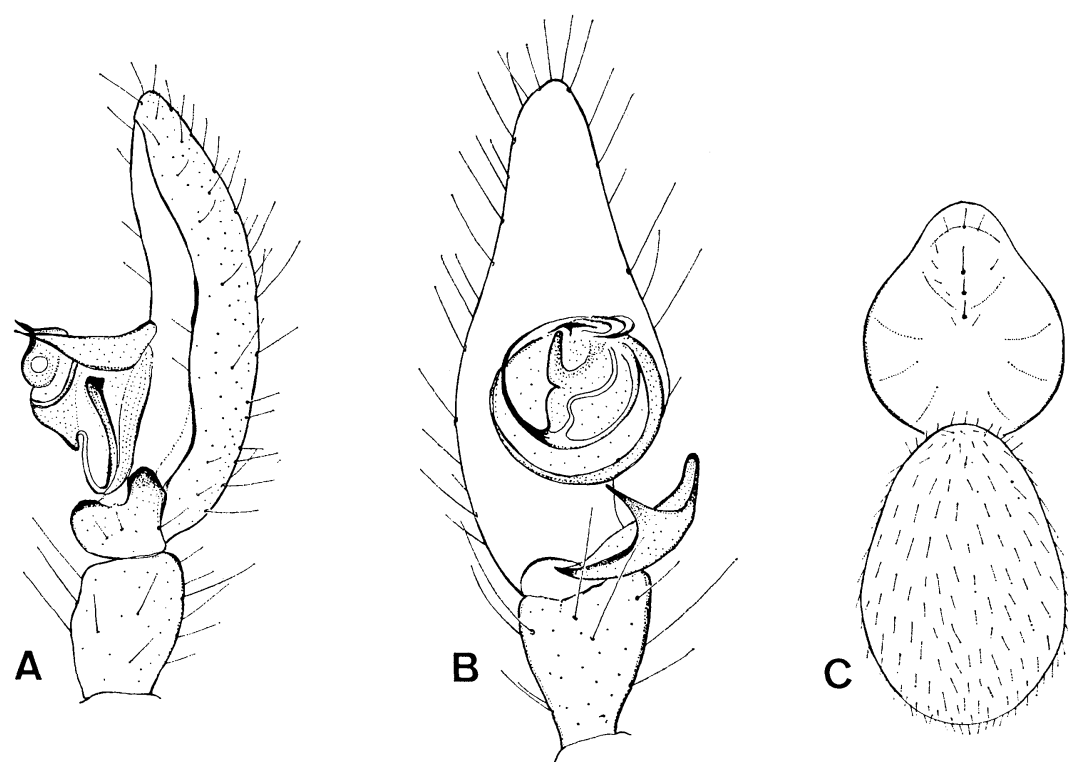

Fig. 6. Nesticus mogera of Tsusaa-gaano-abu Cave on Kurima jima (Miyako Islands): A. B. Male palp. C. Dorsal aspect of the male.

jima, Okierabu jima and Tokuno shima, but has not been able to determine these spiders up to now. Troglophilous species.

\section{Family Linyphiidae}

\section{Linyphia oidedicata (HELSDINGEN, 1969)}

Specimens examined: 1 female and 1 male, Aug. 29, 1970, Mayaa-gama Cave (No. 44).

This spider spins a sheet-web in low bushes. Accidental trogloxenous species.

Distribution: Ryukyu Islanus, Tokara Islands, Tsushima, Kyushu, Shikoku, Honshu and Hokkaido.

\section{Family Symphytognathidae}

\section{Conoculus lyugadinus Komatsu, 1940}

Specimens examined: 2 females, May 22, 1961, Amuji-gama Cave (No. 40); 2 females, Aug. 6, 1971, Terano-gama Cave (No. 35); 7 females, Aug. 3, 1970, Agariisagama Cave (No. 51); 4 females and 3 males, Nov. 30, Gyokusen-do Cave (No. 57); 3 females, Feb. 8, 1971, Kaabuya-gama Cave (No. 36); 1 female, Aug. 30, 1971, Shirohara-dō Cave (No. 33); 1 female, Aug. 30, 1971, Miiga Cave (No. 31); 5 females, and 

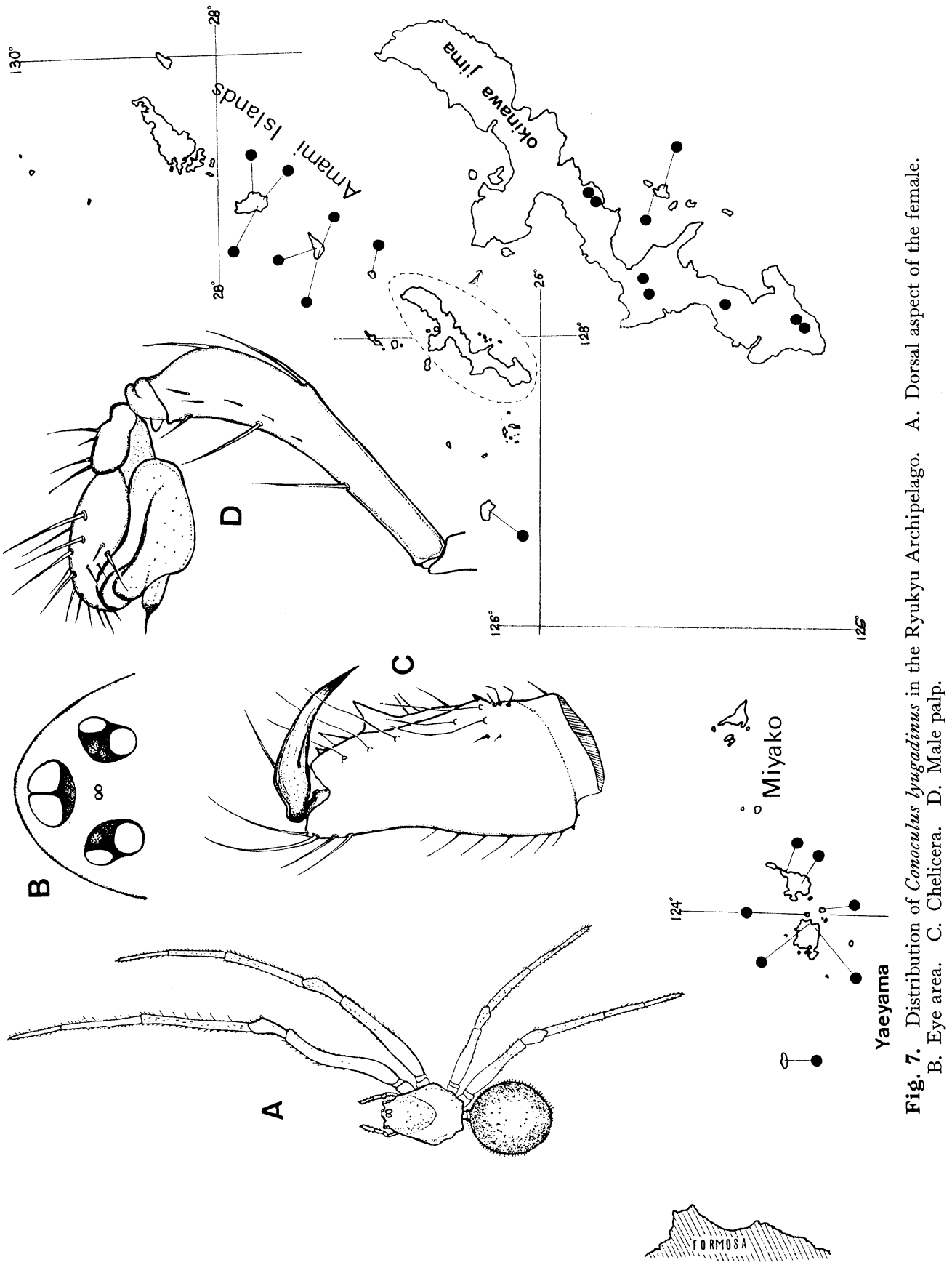
1 male, Jul. 17, 1972, Shinzato-dō Cave (No. 58); 2 females, Sep. 15, 1972, Kanida-gama Cave (No. 42); 1 female, Dec. 27, 1972, Ohōbu-abu Cave (No. 62); 1 female, Oct. 22, 1972, Hyandagu-abu Cave (No. 95); 2 female and 1 male, Oct. 24, 1972, Toyohara-dō Cave (No. 94); 3 females, 2 female youngs and 1 male, Oct. 26, 1972, Daiichi Fukubukuiijaa Cave (No. 77); 1 male, Oct. 27, 1972, Kenno-abu Cave (No. 87); 4 females and 2 males, Oct. 28, 1972, Inoda-iijaa Cave (No. 72); 2 females, Oct. 29, 1972, Zuruku-aboo Cave (No. 86); 2 females, Aug. 6, 1973, Ootomi-dō Cave (No. 90); 3 females and 3 males, Aug. 1, 1972, Kurago Cave (No. 6); 3 females, Aug. 2, 1972, Kenbuii Cave (No. 5); 1 female, Aug. 2, 1972, Maeyama Cave (No. 3); 2 females, Aug. 3, 1972, Shoryu-dō Cave (No. 7); 5 female, Aug. 3, 1972, Erabu-dō Cave (No. 9); 2 females, Aug. 5, 1972, Tenryudō Cave (No. 11); 1 female, 2 female youngs and 2 males, Aug. 6, 1972, Aasaki-abu Cave (No. 12).

This spider weaves a fragile orb-web between rocks, often over the running water in the limestone caves. So far this species has been found inside of the limestone caves in the Ryukyu Islands, but it is collected from both inside and outside of caves in Honshu, Japan. This spider is widely distributed in the Ryukyu Archipelago. Troglophilous spider.

Distribution: Yonaguni jima, Iriomote jima, Kuro shima, Kohama jima, Ishigaki jima, Okinawa jima, Miyagi jima, Kume jima, Yoron jima, Okierabu jima, Tokuno shima, Gotō Islands, Tsushima, Kyushu, Shikoku and Honshu.

\section{Family Argiopidae}

\section{Araneus ventricosus (L. KocH, 1877)}

Specimen examined: 1 female, Oct. 11, 1970, Futenmagu-dō Cave (No. 48).

This is a widely distributed spider in the Ryukyus and Japanese Islands. It is usually found in shady places near human dwellings or open woodland. Accidental trogloxenous species.

Distribution: Ryukyu Islands, Tsushima, Tokara Islands, Kyushu, Shikoku, Honshu and Hokkaido.

Argiope aemula (WALCKenAer, 1873)

Specimen examined: 1 female, Sep. 24, 1972, Nahanshari Cave (No. 17).

This is a widely distributed spider in the Ryukyu Islands, and is usually found in fields. The spider weaves an inclined orb-web, which has a white X-band (stabilimentum) in the central part of the web. Accidental trogloxenous species.

Distribution: Ryukyu Islands, Formosa. 
Gasteracantha mammosa (C. КосH, 1845)

Specimens examined: 1 female, Jul. 23, 1971, Chibisuku-abu Cave (No. 68); 1 female, Jul. 23, 1971, Narikawa-dō Cave (No. 63).

One of the most common species in the Ryukyu Islands. It weaves a complete orb-web in sunny places. Accidental trogloxenous species.

Distribution: Ryukyu Islands, Tokara Islands, Kyushu, Shikoku, Honshu, Formosa and China.

\section{Meta reticuloides YAGINUMA, 1958}

Specimens examined: 3 females, 1 female young and 2 male youngs, Aug. 1, 1972, Kurago Cave (No. 6).

This spider weaves an inclined orb-web in dark places near the entrance of the limestone caves. Scotophilous species.

Distribution: Okinawa jima, Tokuno shima, Amami ooshima, Tsushima, Kyushu, Shikoku and Honshu.

Nephila clavata L. KocH, 1877

Specimen examined: 1 female, Aug. 30, 1971, Miiga Cave (No. 31).

This is a widely distributed species in the Ryukyus and Japanese Islands. An accidental trogloxenous spider.

Distribution: Ryukyu Islands, Tokara Islands, Tsushima, Kyushu, Shikoku, Honshu, Formosa, Korea and China.

\section{Nephila maculata (FABRICIUS, 1793)}

Specimens examined: 1 female, Aug. 30, 1971, Miiga Cave (No. 31); 1 female, Aug. 14, 1970, Yaaji-gama Cave (No. 53).

One of the common species in the Ryukyu Islands, which is often found in open woodlands. The female of this species is the largest spider in Japan, but the male is very much smaller. Accidental trogloxenous spider.

Distribution: Ryukyu Islands, Tokara Islands, Formosa and China.

Cyclosa argenteoalba BöSENBERG et STRAND, 1906

Specimen examined: 1 female, Sep. 8, 1972, Taabaru-gama Cave (No. 49).

This spider spins a small orb-web in open woodland. Accidental trogloxenous spider.

Distribution: Ryukyu Islands, Amami ooshima, Tokara Islands, Kyushu, Shikoku, Honshu, Hokkaido and Sakhalin. 


\section{Cyclosa insulana (Costa, 1834)}

Specimens examined: 1 female, Sep. 11, 1970, Futenmagu Cave (No. 48 ); 1 female, Jul. 23, 1971, Narikawa-dō Cave (No. 63).

One of the most common species in the Ryukyus and Japanese Islands. Habit of this species is similar to that of Cyclosa argenteoalba.

Distribution: Ryukyu Islands, Tsushima, Tokara Islands, Ogasawara, Kyushu, Shikoku, Hokkaido, Formosa and China.

\section{Cyclosa mulmeinensis (THORELL, 1887)}

Specimens examined: 1 male, Oct. 2, 1970, Futenmagu Cave (No. 48); 1 female, Aug. 29, 1970, Mayaa-gama Cave (No. 44).

This spider is often found in open woodland or seaside areas. It is widely distributed in the Ryukyu Islands. Accidental trogloxenous spider.

Distribution: Ryukyu Islands and Formosa.

\section{Cyrtophora moluccensis (DOLESCHALL, 1857)}

Specimens examined: 2 females, Aug. 26, 1970, Nisshu-do Cave (No. 34); 1 female, Aug. 14, 1970, Yaaji-gama Cave (No. 53).

This spider is widely distributed in the Ryukyu Chain. The female of this species spins a large dome-web in open woodland. Accidental trogloxenous spider.

Distribution: Ryukyu Islands, Tokara Islands, Yakushima, Kyushu, Shikoku, Honshu and Formosa.

\section{Family Tetragnathidae}

Leucauge blanda (L. KocH, 1877)

Specimens examined: 1 female, Aug. 14, 1970, Yaaji-gama Cave (No. 53); 1 female, Aug. 29, 1970, Mayaa-gama Cave (No. 44).

This is a widely distributed species in the Ryukyu Islands, which is often found in bushes or in open woodlands. Accidental trogloxenous spider.

Distribution: Ryukyu Islands, Tokara Islands, Tsushima, Yakushima, Kyushu, Shikoku, Honshu, Formosa and China.

\section{Family Pisauridae}

Dolomedes raptor BöSEnBERG et STRAND, 1906

Specimen examined: 2 females, Aug. 30, 1971, Shirohara-dō Cave (No. 33). 
This spider inhabits in rocky areas of streams near the forest or in swampland. Accidental trogloxenous spider.

Distribution: Okinawa jima, Amami ooshima, Nakano shima (Tokara Islands), Kyushu, Shikoku and Formosa.

Parenethis fascigera (BösenBerg et STRAND, 1906)

Specimen examined: 1 female, Aug. 14, 1970, Yaaji-gama Cave (No. 53).

This spider is found on cultivated fields or in open woodland. Accidental trogloxenous spider.

Distribution: Ryukyu Islands, Amami ooshima, Kyushu, Shikoku and Honshu.

\section{Family Lycosidae}

Lycosa pseudoannulata (BöSENBERG et STRAND, 1906)

Specimens examined: 3 females, Aug. 22, 1970, Shimuku-gama Cave (No. 37); 2 females, Sep. 8, 1970, Taabaru-gama Cave (No. 49); 1 females, Feb. 8, 1971, Kaabuyagama Cave (No. 36); 1 female, Jul. 23, 1971, Agari-isagama Cave (No. 51); 2 female youngs, Aug. 14, 1971, Yaaji-gama Cave (No. 53); 3 females, Sep. 15, 1972, Kanidagama Cave (No. 41); 1 female, Sep. 23, 1972, Niiyatiya Cave (No. 18); 2 females, Oct. 26, 1972, Daiichi Fukubuku-iijaa Cave (No. 77).

This spider is often found in paddy fields or swampland in the Ryukyu Islands. Accidental trogloxenous spider.

Distribution: Ryukyu Islands, Amami ooshima, Tokara Islands, Kyushu, Shikoku, Honshu, Hokkaido, Korea, China and Skahalin.

\section{Family Salticidae}

\section{Plexippus paykulli (Audouin, 1827)}

Specimen examined: 1 female, Aug. 30, 1970, Agari-isagama Cave (No. 51). One of the common species in the Ryukyu Islands. It is often found around human dwellings. Accidental trogloxenous species.

Distribution: Ryukyu Islands, Tokara Islands, Ogasawara, Kyushu, Shikoku, Honshu, Hokkaido, Formosa and Korea.

\section{Hasarius adansoni (AUdOUIN, 1827)}

Specimens examined: 1 female, Oct. 25, 1972, Yanga Cave (No. 84); 2 females, Oct. 21, 1972, Ubunuti-abu Cave (No. 99). 
This jumping spider has the same habit as the preceding species. Accidental trogloxenous spider.

Distribution: Ryukyu Islands, Tokara Islands, Ogasawara, Kyushu, Shikoku, Honshu and Hokkaido.

\section{Myrmarachne japonica (KARSCH, 1879)}

Specimen examined: 1 female, Oct. 11, 1970, Futenmagu Cave (No. 48).

General feature of this species resembles the ant, and is often found in open woodland or in grassfield. Accidental trogloxenous spider. Animal was collected by Yoshio Arakaki.

Distribution: Ryukyu Islands, Amami ooshima, Tokara Islands, Tsushima, Kyushu, Shikoku, Honshu, Formosa and Korea.

\section{Family Glubionidae}

\section{Orthobula crucifera BöSENBERG et STRAND, 1906}

Specimen examined: 1 female, Jul. 31, 1972, Nanatii-gama Cave (No. 1).

This small spider lives among fallen leaves or in forest litters. Trogloxenous spider.

Distribution: Kume jima, Koobi-sho (Senkaku Islands), Kikai jima (Amami Islands), Suwanose jima (Tokara Islands), Kyushu, Shikoku, Honshu and Korea.

\section{Family Heteropodidae}

\section{Heteropoda forcipata (KARSCH, 1881)}

Specimens examined: 2 females, Aug. 25, 1970, Nisshu-dō Cave (No. 34); 1 female, Jul. 23, 1971, Abucha Cave (No. 67); 1 female, Jul. 23, 1971, Chibisuki-abu Cave (No. 68); 1 female, Jul. 23, 1971, Isagana Cave (No. 65); 2 females and 1 male, Oct. 22, 1972 , Hyandagu Cave (No. 95); 1 female, Oct. 26, 1972, Daiichi Fukubuku-iijaa Cave (No. 77); 2 females, Oct. 28, 1972, Inoda-iijaa Cave (No. 72); 1 female, Oct. 29, 1972, Zurukuaboo Cave (No. 86); 1 female and 1 male, Oct. 24, 1972, Ootomi-dō Cave (No. 90).

This spider lives in the forest or near the entrance of the caves. Scotophilous spider.

Distribution: Ryukyu Islands, Amami ooshima, Tsushima, Kyushu, Shikoku, Honshu and Formosa.

\section{Heteropoda venatoria (LINNE, 1758)}

Specimen examined: 1 female, Oct. 11, 1970, Futenmagu Cave (No. 48). One of the common species in the tropics or subtropics, and is often found in human dwellings or in the forest. Scotophilous spider. 
Distribution: Ryukyu Islands, Tokara Islands, Ogasawara, Kyushu, Shikoku, Honshu, Formosa, Korea and China.

\section{Family Ctenidae}

\section{Anahita fauna $\mathrm{KARSCH}, 1879$}

Specimens examined: 1 female, Aug. 3, 1970, Agari-isagama Cave (No. 51); 2 females, Aug. 25, 1970, Nisshu-dō Cave (No. 34); 1 female, Sep. 8, 1970; 1 female, Feb. 19, 1972, Taabaru-gama Cave (No. 49); 1 female, Oct. 11, 1970 (Y. Arakaki), Futenmagu Cave (No. 48); 1 female, Feb. 8, 1971, Kaabuya-gama Cave (No. 50); 1 female, Jul. 23, 1971, Higashi-narikawa Cave (No. 64); 1 female, Aug. 30, 1971, Miiga Cave (No. 31); 1 female, Aug. 30, 1971, Shirohara-dō Cave (No. 33); 1 female, Sep. 9, 1972, Nobaru-gama Cave (No. 28); 1 female, Jul. 31, 1972, Nanatii-gama Cave (No. 1).

This spider is widely distributed in the Ryukyu Islands, which is often found in shady grassfields or in the forest litters. Accidental trogloxenous spider.

Distribution: Ryukyu Islands, Tokara Islands, Kyushu, Shikoku, Honshu, Hokkaido, Formosa, Korea and China.

\section{Family Gnaphosidae}

\section{Drassodes oculinotatus BösENBERG et STRAND, 1906}

Specimen examined: 1 female, Oct. 11, 1970, Futenmagu Cave (No. 48).

This spider inhabits under stones or fallen leaves in the forest. Accidental trogloxenous spider.

Distribution: Okinawa jima, Kyushu, Honshu and Korea.

\section{Remarks}

As mentioned above, a survey of the cave spider fauna in the Ryukyu Archipelago was carried out by the author. As the results obtained, 42 species of 36 genera belonging to 23 families were recognized from the limestone caves in the Ryukyu Chain. By the degree of adaptation to the subterranean environments, these spiders are discriminated in the following groups, as listed below:

Troglobiontic species......Live in caves only, most adaptive to the subterranean environments.

Masirana longipalpis, Falcileptoneta okinawaensis and Speocera laureata.

Troglophilous species......Usually lives in caves but seldom in the dark moist places or in the forest debris. 
Tetrablemma shimojanai, Nesticus mogera and Conoculus lyugadinus.

Scotophilous species..... Usually lives in dark places but sometimes found in caves.

Heptathela kimurai, Macrothele holsti, Latouchia swinhoei, Ummidia fragaria, Uloborus varians, U. geniculatus, Ischnothyreus narutomii, Scytodes thoracica, Smeringopus pallidus, Coleosoma blandum, Theridion tepidariorum, Orthobula crucifera and Heteropoda forcipata.

Trogloxenous species...... Usually found in outside of caves but rarely met with in caves.

Linyphia oededicata, Conopistha bonadea, C. fissifrons, Araneus ventricosus, Argiope aemula, Cyclosa argenteoalba, C. insulana, C. mulmeinensis, Cyrtophora moluccensis, Gasteracantha mammosa, Meta reticuloides, Nephila maculata, $N$. clavata, Leucauge blanda, Dolomedes raptor, Perenethis fascigera, Lycosa pseudoannulata, Plexipus paykulli, Hasarius adansoni, Myrmarachne japonica, Heteropoda venatoria, Anahita fauna and Drassodes oculinotatus.

As remarked above, the troglobiontic spiders in the Ryukyu Archipelago are few, and most of cave spiders found in the islands are scotophilous or trogloxenous species. But so far as concerned with the individuals belonging to Nesticid spiders obtained from the limestone caves in the Miyako Islands, they have a troglobiontic features. In the females of genus Nesticus, the eyes are completely degenerated.

Five species have proved to be new to science among the spiders obtained. One species of them, is Hexablemma sp. (Fam. Tetrablemmidae) and which is a remarkable species from both a taxonomical and a zoogeographical view-points. The other four species belonging to genus Hexablemma are hitherto known from East Africa, West Africa and western Samoa. Tetrablemma shimojanai (Fam. Tetrablemmidae) spreads from the Yaeyama to Tokara Islands, so its distribution is distinctly continuous over the chain of islands. Both genera belong to the family Tetrablemmidae, which are distributed in the tropical and subtropical regions of the world.

As mentioned above, Tetrablemma shimojanai has a wider range of distribution than that of Hexablemma sp. The representative species of Leptonetid spider in the Ryukyu Islands are Masirana longipalpis and Falcileptoneta okinawaensis. The former is spread over Ishigaki jima, Okinawa jima, Miyagi jima, Ie jima, Kouri jima, Hamahiga jima, Ikei jima, Tonaki jima and Kume jima. The population of $M$. longipalpis in Okinawa jima is much adapted to the subterranean environments. The male palp of Masirana longipalpis is the longest hitherto known in the Leptonetid spiders in Japan.

The eyes and body-color of this species is more or less degenerated. In some of Oki- 
nawa jima's population, the eyes are completely degenerated. On the other hand, the eyes and body-color of the population in Ishigaki jima are not similar to the species found in Okinawa jima. The distribution of Falcileptoneta okinawaensis is limited in Okinawa jima. This species has been found in the limestone caves only. Considering some features of this species, it does not seem to be adapted to the subterranean environments as compared with Masirana longipalpis.

In the Amami Islands, the endemic species of cave spider has not been described up to now. But the present author has collected three different species belonging to family Leptonetidae from Yoron jima, Okierabu jima and Tokuno shima, which are probably new to science. The male palp of each spider is shown in Fig. 4.

Speocera laureata one of the troglobiontic spiders, is widely distributed in the Ryukyu Archipelago. I should study further on the morphological variation of this species obtained from each island. Conoculus lyugadiuns one of the troglophilous spiders, is widely distributed in the Ryukyus and Japanese Islands, but the local differentiation of it has not been observed. This species has not been found in Miyako Islands and Daito Islands.

The Ryukyu Archipelago is very poor in the Leptonetid spiders as compared with the Japanese Islands. At present, the representative species of the cave dwelling spiders in the Ryukyu Archipelago are Masirana longipalpis, Falcileptoneta okinawaensis, Speocera laureata and Tetrablemma shimojanai.

Among of them, Speocera laureata and Tetrablemma shimojanai are widely distributed in the Ryukyu Chain, but they have not been found in the Miyako Islands.

As mentioned above, the cave spider fauna of the Ryukyu Archipelago is much different from the Japanese Islands. The author has collected several different species from the limestone caves in the Ryukyu Chain, but has not been able to determine these spiders up to now. Many difficult problems on the cave spiders obtained from the Ryukyus remained. I wish to resolve these problems in future, especially both on the differentiations and zoogeographical distribution of each species.

\section{Summary}

1. In this paper are briefly described on the spiders obtained from the limestone caves in the Ryukyu Archipelago.

2. Fourty two species of thirty six genera belonging to twenty three families have been found in the limestone caves (excluding indetermined species). Among them, only three species are troglobiontic spider.

3. The representative spiders of the limestone caves in the Ryukyu Archipelago are 
Masirana longipalpis, Falcileptoneta okinawaensis, Speocera laureata and Tetrablemma shimojanai.

4. Masirana longipalpis is most adapted to the subterranean environments among troglobiontic spiders.

5. Speocera laureata and Tetrablemma shimojanai are the most widely spread spiders in the limestone caves in the Ryukyu Chain.

6. Okinawa jima has more abundant cave spider fauna than the other islands.

7. The cave spider fauna of the Ryukyu Archipelago is much different from the Japanese Islands.

摘 要

下謝名松栄（沖縄県古普天間高等学校，干901-22 沖縄県宜野湾市字普天間585）：琉球弧における石 灰洞産クモ相予報.

1. 本稿は琉球弧における石灰洞のクモ相の概要について述べたものである.

2. 調查した石灰洞から 23 科 36 属 42 種が得られたが，その中で真洞窟種はわずかの 3 種である.

3. 琉球弧の石灰洞を表徵する種類は，ウデナガヒナマシラグモ Masirana iongipalpis，オキナワマ シラグモ Falcileptoneta okinawaensis, カンムリグモ Speocera laureata とジャバラグモ Tetrablemma shimojanai の 4 種である.

4. 真洞窟種の中では, ウデナガヒナマシラグモが最も洞窟環境に適応している.

5. カンムリグモとジャバラグモは最む広い分布をなす洞窟種である.

6. 琉球弧の中では, 汁縄島が最む洞窟珄クモ相に富んでいる.

7. 琉球弧における洞窟甡のクモ相は，日本列島の洞窟産のクモ㥵とは大変異なっている.

\section{References}

Bryant, E. B., 1940. Cuban spiders in the Museum of Comparative zoology, Bull. Mus. Comp. Zool. Harvard, 86(7): 249-532.

Brignol.I, P. M., 1972. Some cavernicolous spiders from Mexico (Araneae). Quard. Acc. Naz., Lincei, 171 : $129-155$.

1974. Tetrablemmidae (Araneae) dell'Angola e dello Zaire. Subsidios Para o Estudo da Biologia Na Lunda, 179-195.

1974. On some Oonopidae from Japan and Formosa (Araneae), Acta Arachnol. 25: 73-85.

Komatsu, T., 1968. Two new cave spiders of genera Tetrablemma (Tetrablemminae, Oonopidae) and Dolichocybaeus (Cybaeinae). Acta Arachnol., 21 : 35-38.

1972. Two new cave spiders from Okinawa Island (Genera Falcileptoneta, and Masirana, Leptonetidae). Acta arachnol. 24: 82-85.

1974. A new cave spider of the genus Speocera (Araneae: Ochyroceratidae). Acta arachnol., 25: 44-46.

Marples, B. J., 1955. Spiders from Western Samoa. J. Linn. Soc. London, 42: 453-504.

Roewer, C. F., 1963. Orthognatha, Labidognatha. Insects of Micronesia, 3(4): 124-127. 
Shimojana, M. 1973. Results of the speleological survey in Yaeyama Islands. Okinawa Assoc. Biol. Educ., (6) 1-26. (in Japanese).

Yaginuma, T. 1963. Spiders from limestone caves of Akiyoshi Plateau. Bull. Akiyoshi-Dai Sci. Mus., (2): 49-62. (in Japanese with English summary).

1962. Cave spiders in Japan. Bull. Osaka Mus. Nat. Hist., (15): 65-77. (in Japanese with English summary).

1970. The spider fauna of Japan (revised in 1970). Bull. Natn. Sci. Mus. Tokyo, 13: 639-701. (in Japanese with English summary).

1970. The fauna of the insular lava caves in West Japan. IV. Araneae (part 1). Bull. Natn. Sci. Mus. Tokyo, 13: 623-629.

1970. Two new species of small, nesticid spiders of Japan. Bull. Natn. Sci. Mus. Tokyo, 13: 385-394.

1971. Cave spiders of Japan. Atypus, (57) Appendix: 1-6. (in Japanese).

1972. Revision of the short-legged nesticid spiders of Japan. Bull. Natn. Sci. Mus.

Tokyo, 15: 619-622.

1960. Spider of Japan in Colour. Osaka. pp. i-Viii $+1-197$, pls. 1-56. (in Japanese). 